\title{
Doença infecciosa bursal: avaliação da patogenicidade de vacinas comercializadas no Brasil em aves livres de patógenos específicos ${ }^{*}$
}

\author{
ADRIANA PADILHA DE PADILHA
}

Carlos Tadeu Pippi Salle (Orientador - UFRGS)

Hamilton Luiz de Souza Moraes (Co-Orientador - UFRGS)

Banca: Vladimir Pinheiro do Nascimento (UFRGS), Elci Lotar Dieckil (UPF), Maristela Lovato Flores (UFSM)

A doença infecciosa bursal (DIB) é uma enfermidade viral, que acomete galinhas provocando imunodepressão sendo, economicamente, importante para a indústria avícola. O controle da DIB é realizado através de diferentes vacinas assim como programas de vacinação. No presente trabalho, a patogenicidade de três vacinas intermediárias (I1, I2 e I3), duas intermediárias mais patogênicas (IP1, IP2) e três vacinas contendo vírus forte (F1, F2 e F3) foi avaliada. Foram utilizadas 90 aves livres de patógenos específicos (LPE) divididas, igualmente, em 9 grupos sendo 1 grupo para cada diferente vacina e 1 grupo controle. As aves dos 8 grupos receberam as diferentes vacinas, através da via ocular, aos 21 dias de idade e todos os animais foram pesados e sacrificados ao completarem 28 dias. Foram coletadas uma amostra de sangue e a bolsa de Fabricio (BF) de cada ave. O soro foi utilizado na mensuração do título de anticorpos através da técnica ELISA e as bolsas de Fabricio foram pesadas, medidas e encaminhadas para análise histológica. Aves vacinadas com IP1, IP2, F1, F2 e F3 apresentaram tamanho da bolsa de Fabrício, significativamente, menor em relação ao grupo controle e aos animais vacinados com I1, I2 e I3. Por outro lado, a vacina I3 produziu título de anticorpos semelhante ao grupo controle diferindo de todas as demais vacinas. Porém I1 e I2 induziram títulos de anticorpos maiores que o grupo controle, sendo que I1 promoveu a formação de título de anticorpos semelhante à IP1, IP2, F1, F2 e F3. Os escores de lesão histopatológica mostraram que I1, I2 e I3 induziram graus similares de lesão da bolsa, sendo que I2 e I3 não diferiram do grupo controle, enquanto I1 apresentou diferença. As vacinas intermediárias mais patogênicas, assim como as vacinas “fortes" promoveram escores de lesão, significativamente, maiores que as demais vacinas testadas. Esses resultados sugerem que as vacinas intermediárias mais patogênicas e as vacinas "fortes” são capazes de causar severos danos na bolsa de Fabrício. Também foi possível inferir que a bursometria pode ser inadequada para a avaliação vacinal, porém pode ser utilizada na escolha da vacina para programas de vacinação. Além disso, observou-se que as vacinas "fortes" induziram a formação de títulos de anticorpos mais altos que as demais vacinas, porém algumas vacinas intermediárias são capazes de promover títulos semelhantes.

Descritores: Doença infeciosa da bolsa, bolsa de Fabricio, lesão, vacinas, imunodepressão. 


\title{
Infectious bursal disease: evaluation of pathogenicity of comercial vaccines from Brazil in specific pathogen free chickens*
}

\author{
ADRIANA PADILHA DE PADILHA
}

Carlos Tadeu Pippi Salle (Adviser - UFRGS)

Hamilton Luiz de Souza Moraes (Co-Adviser - UFRGS)

Committee: Vladimir Pinheiro do Nascimento (UFRGS), Elci Lotar Dieckil (UPF), Maristela Lovato Flores (UFSM)

Infectious bursal disease (IBD) is a chicken disease economically important for the poultry industry in function of the immune depression that it causes. Disease control is made with different vaccines and vaccination programs. In present work, the pathogenicity of 3 intermediate vaccines (I1, I2 and I3), 2 intermediate more pathogenic (IP1 and IP2) and 3 vaccines containing strong virus (F1,F2 and F3) was evaluated. Ninety Specific Pathogen Free (SPF) birds were distributed in 9 groups with 10 animals each. The groups were vaccinated with one vaccine sample each and one last group was the control group The birds of eight experimental group were submitted to ocular vaccination at 21 days old. At 28 days of age, birds were weighed, slaughtered and bursas of Fabricius (BF) diametrs were measured Histological lesion scores in the bursas were defined for each vaccine. Serum samples were collected from the 90 birds before slaughter at 28 days of age and IBDV (Infectious Bursal Disease Virus) antibody levels were evaluated using a comercial ELISA kit. Birds vaccinated with IP1, IP2, F1, F2 and F3 showed significantly lower bursa size in relation to control animals and animals vaccinated with I1, 12 and I3. On other hand, the vaccine I3 induced antibody titers similar to control group and was different from the all other vaccines. Nevertheless, I1 and I 2 induced antibody titers higher than the control and I1 induced antibody titers similar to IP1, IP2, F1, F2 e F3. Histological scores showed that vaccines I1, I2 and I3 induced similar injury degree, although I 2 and I 3 were not different from the control, whereas I1 was significantly different. Strong vaccines induced more pronounced lesions than the other tested vaccines. These findings suggest that strong vaccines are able to cause severe bursal injuries. However, bursometry and relative weight of the bursa of Fabricius were considered inadequate to evaluate vacination programs, but it can be used to choice of vaccines to vacination programs. Moreover, strong vaccines induced higher antibody titers than the other vaccines, although some intermediate vaccines induced similar titers.

Key words: Infectious bursal disease, bursa of Fabricius, lesion, vaccines, immune depression. 